\title{
Study on the Management System of Marketization Allocation of Marine Resources in China
}

\author{
CHEN Pei-xiong \\ Ocean Engineering Institute \\ The Second Institute of Oceanography, SOA \\ Hangzhou, China \\ ZHANG He \\ Ocean Engineering Institute \\ The Second Institute of Oceanography, SOA \\ Hangzhou, China
}

\author{
XIANG Yunyun \\ Ocean Engineering Institute \\ The Second Institute of Oceanography, SOA \\ Hangzhou, China \\ NING Yue \\ Ocean Institute \\ Zhejiang University \\ Hangzhou, China
}

\begin{abstract}
The market-oriented allocation of sea resources is the process of allocation between sea resources and the use objects. To find a more suitable sea user through the allocation methods on specific sea areas is the direct object of the allocation of resources in China's sea area. That is of great significance for achieving the appreciation and the allocation of rational resources. Based on the analysis of the existing problems in the process of market-oriented allocation of marine resources in our country, this paper summarizes the market-oriented allocation of marine resources in the whole country for the first time and proposals a systematic theoretical guidance and normative policy designs in the aspects of overall organization, system construction, operation practices, market cultivation and actualization guarantee. The research results have a guiding role in continuously improving the institutional framework of China's market-oriented allocation of sea resources and regulating the transfer behavior across the country.
\end{abstract}

Keywords-Sea resources; Administrative distribution; Marketization allocation; Management system

\section{INTRODUCTION}

Marine resource is an important space for marine development and utilization activities and a basic carrier for marine economic development [1]. With the development and expansion of China's marine economy, the demand for marine resources will increase, and the rational allocation of marine resources will become an important task in marine management.

The allocation of sea resources is the process of allocation between sea resources and the sea users. The direct goal of the allocation of resources in the sea area is to find a suitable sea user for the specific sea area using the allocation method [2]. Meanwhile, currently China's marine resources allocation is dominated by administrative allocation and market allocation.

Under the planned economic system in the past, the means of production were subject to public ownership. The state allocated resources through unpaid appropriation and free transfer. Simultaneously, the users, as part of the public- owned economy, also had the right to use resources at no cost. As a result, many users do not consider the using efficiency of the sea area, arbitrarily occupy the sea area and waste marine resources. The "Law of the People's Republic of China on the Administration of the Use of Sea Area", which was put into effect in 2002, marked the beginning of the institutional shift in the use of water in our country from non-reimbursable use to paid use and was also the beginning of marketization of China's marine resources [1]. The Third Plenary Session of the 18th CPC Central Committee made it clear that "we must actively and steadily push forward the marketization reform in a broad and deep manner, substantially reduce the government's direct allocation of resources and promote the maximization of resources based on market rules, market prices and market competition with the efficiency optimization". This conference repositioned the market's position and role in the resource allocation. The market's position in the allocation of resources rose from a basic role to a decisive one, objectively requiring a more stringent primary market and a faster secondary market. of China's maritime resources.

\section{ALLOCATION RANGES OF CHINA'S MARINE RESOURCES MARKET}

There are mainly two ways of resource allocation: administrative allocation and market allocation [3]. Similarly, the way of allocation of resources in China's sea area mainly includes market allocation and administrative allocation. On the other hand, China's maritime circulation market includes the primary market, the secondary market and the middle market. As shown in Fig. 1, the primary market supports the state transfers its sea area right to the sea users according to law, including the examination and approval of administrative allocation and the methods of bidding, auction and listing for market allocation. In the second market the sea users can subcontract the sea area to a third party in the use period. The valid activities include transfer (sale, gift, price shares, exchange, etc.), rental, mortgage, inheritance and so on. Hence, it is clear that the waters of our country Market allocation of 
resources is an integral part of the primary market, and completely covers the secondary market [2].

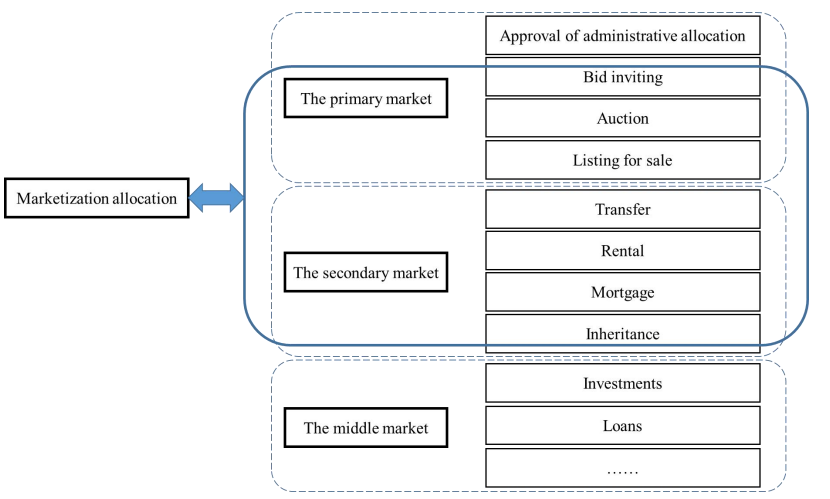

FIG. 1. The market allocation range of China's marine resources

\section{THE CURRENT MARKET-ORIENTED ALLOCATION OF RESOURCES MANAGEMENT CONTROL SYSTEM}

\section{A. Transfer system of the sea}

The transfer methods of the marketization marine resources main contain bidding, auction and listing transfer. Bidding, auction or listing collectively referred to as the bidding system, initially originated in Europe and the United States, and later widely used in Hong Kong. The form of land bidding and auctioning in our country is formulated according to the rules of that in Hong Kong. Sea resources and land resources are quite similar, which both belong to the resources of assets and the management of sea resources also implements the same bidding system. At present, China's sea operation is implementing the system of inviting auction bidding.

The right to use the sea for bidding and transferring is one of the ways to search for developers in the market who could benefit the national development plans depending the vote for sea users in the sea using bids composed of specific citizens, legal persons or other organizations, after the governments have clearly definition on the intent and planning conditions for a certain sea area. In addition, the right to use the auction sea area refers to a method determine the transferee based on "the highest bidder" principle in the competitive tender for selling the sea use in the specific time and place with qualified assignees after the governments have clearly definition on the intent and planning conditions for a certain sea area [4]. The right to use the sea for the listing transfer means the behavior of conforming the sea users according to the time limit set by the announcement after the governments have clearly definition on the planning conditions for a certain sea area. Meanwhile, the municipal and county people's governments would issue a notice on the listing, make the trading conditions of the sea area to be transferred and accept bidding application before updating the listing price, in terms of the listing deadline bidding results to determine the behavior of sea users. On the other hand, the bidding, auction or listing is a highly marketed form of transfer. It is a transaction under the sun and fully reflects the principle of openness, fairness and fairness. Additionally, the system of bidding and auctioning of the right to use the sea is more conducive to the marketization of marine resources with high efficiency and high transparency.

"The Regulation on the Management of the Right to Use Sea Areas" specifies the conditions of bid invitation and auction for the right to use sea areas, the basis for plan preparation, the departments responsible for the examination and approval, the announcement of the transfer, the price and the contract of assignment. As shown in Table 1, Hebei Province, Shandong Province, Zhejiang Province, Fujian Province and Hainan Province successively promulgated the provisions on the marketization of the right of sea use, or regulated the market-oriented transfer of the right to use sea areas in the relevant provisions.

TABLE I. THE MANAGEMENT DOCUMENTS OF TRANSFER SYSTEM OF SEA USE RIGHTS IN SOME LOCAL SEA REGIONS

\begin{tabular}{|c|c|c|}
\hline NO. & Documents & $\begin{array}{c}\text { Document } \\
\text { number/ time }\end{array}$ \\
\hline 1 & $\begin{array}{l}\text { The Interim Management Approach of the Right } \\
\text { to Use the Auction Bidding Auction Transfer in } \\
\text { Shandong Province }\end{array}$ & $\begin{array}{l}\text { Lu Sea Fishery } \\
(2016) / \text { No. } 103\end{array}$ \\
\hline 2 & $\begin{array}{l}\text { The Management Approach of Selling the Right } \\
\text { to Use the Sea in Hainan Province }\end{array}$ & $\begin{array}{l}\text { Qiong Fu }(2015) / \\
\text { No. } 9 \\
\end{array}$ \\
\hline 3 & $\begin{array}{c}\text { The Management Approach of Bidding and } \\
\text { Auctioning the Transfer of the Right to Use the } \\
\text { Sea in Hebei Province }\end{array}$ & $\begin{array}{l}\text { Ji Sea Fa }(2013) / \\
\text { No.16 }\end{array}$ \\
\hline 4 & $\begin{array}{l}\text { The Interim Management Approach of Bidding } \\
\text { and Auctioning the Transfer of the Right to Use } \\
\text { the Sea in Zhejiang Province }\end{array}$ & $\begin{array}{l}\text { Zhe Hai fishery } \\
(2013) / \text { No. } 6\end{array}$ \\
\hline 5 & $\begin{array}{l}\text { The Approach of Bidding and Auctioning the } \\
\text { Transfer of the Right to Use the Sea in Fujian } \\
\text { Province }\end{array}$ & $\begin{array}{l}\text { Min Sea fishery } \\
(2007) / \text { No. } 35\end{array}$ \\
\hline 6 & $\begin{array}{l}\text { The Management Approach of Bidding and } \\
\text { Auctioning the Transfer of the Right to Use the } \\
\text { Sea in the Free Trade Zone in Fujian Province }\end{array}$ & 2015.09 \\
\hline 7 & $\begin{array}{l}\text { The Approach of Bidding and Auctioning the } \\
\text { Transfer of the Right to Use the Sea in } \\
\text { Huangdao District of Qingdao City }\end{array}$ & $\begin{array}{c}\text { Qing Huang } \\
\text { Zheng (2015)/ No. } \\
9\end{array}$ \\
\hline 8 & $\begin{array}{l}\text { The Approach of Bidding and Auctioning the } \\
\text { Transfer of the Right to Use the Sea in Weihai } \\
\text { City }\end{array}$ & $\begin{array}{l}\text { Wei Zheng Ban } \\
(2012) / \text { No. } 81\end{array}$ \\
\hline 9 & $\begin{array}{c}\text { The Approach of Bidding and Auctioning the } \\
\text { Transfer of the Right to Use the Sea in } \\
\text { Zhangzhou City }\end{array}$ & $\begin{array}{l}\text { Zhang Zheng Ban } \\
(2012) / \text { No. } 236\end{array}$ \\
\hline 10 & $\begin{array}{c}\text { The Implementation Approach of Bidding and } \\
\text { Auctioning the Transfer of the Right to Use the } \\
\text { Sea in Rizhao City }\end{array}$ & $\begin{array}{l}\text { City Government/ } \\
\text { No. } 28\end{array}$ \\
\hline 11 & $\begin{array}{c}\text { The Management Approach of Bidding and } \\
\text { Auctioning the Transfer of the Right to Use the } \\
\text { Sea in Haikou City }\end{array}$ & $\begin{array}{l}\text { Hai Fu }(2008) / \\
\text { No. } 32\end{array}$ \\
\hline 12 & $\begin{array}{l}\text { The Management Approach of Bidding and } \\
\text { Selling the Right to Use the Sea in Sanya City }\end{array}$ & $\begin{array}{l}\text { San Fu }(2006) / \\
\text { No. } 95 \\
\end{array}$ \\
\hline 13 & $\begin{array}{l}\text { The Implementation Approach of Bidding and } \\
\text { Auctioning the Transfer of the Right to Use the } \\
\text { Sea in Lianyungang City }\end{array}$ & $\begin{array}{l}\text { Lian Zheng } \\
(2004) / \text { No. } 206\end{array}$ \\
\hline 14 & $\begin{array}{c}\text { The Implementation Approach of Bidding the } \\
\text { Transfer of the Right to Use the Sea in } \\
\text { Yancheng City }\end{array}$ & $\begin{array}{c}\text { Yan Zheng (2003) } \\
\text { No. } 233\end{array}$ \\
\hline 15 & $\begin{array}{c}\text { The Temporary Regulation of Transfer } \\
\text { Assignment of the Right to Use the Sea in } \\
\text { Beihai City }\end{array}$ & $\begin{array}{l}\text { Bei Zheng (2003)/ } \\
\text { No. } 24\end{array}$ \\
\hline 16 & $\begin{array}{l}\text { The Temporary Regulation of Bidding and } \\
\text { Selling the Right to Use the Sea in Huizhou City }\end{array}$ & $\begin{array}{l}\text { Hui Fu }(2003) / \\
\text { No. } 12\end{array}$ \\
\hline
\end{tabular}




\section{B. Sea area transfer system}

The equations are an exception to the prescribed specifications of this template. You will need to determine whether or not your equation should be typed using either the Times New Roman or the Symbol font (please no other font). To create multileveled equations, it may be necessary to treat the equation as a graphic and insert it into the text after your paper is styled.

In a broad sense, the transfer of the right to use sea areas includes the transfer of trading rights, the exchange of land use rights, the granting of gifts and the investment of shares in the sea area. The legal feature is the change of the subject of the right to use sea areas. Article 27 of the "Law of the People's Republic of China on the Administration of the Use of Sea Areas" stipulates that the right to use sea areas may be transferred according to law, but its provisions are too principled. Besides, although the law empowers formulated specific measures for the transfer of the right to use sea areas, the specific measures have not been promulgated [5]. "The Regulation on the Management of the Right to Use Sea Areas" further regulated the transfer of the right to use sea areas according to the "Sea Area Law", including the conditions of transfer, examination and approval procedures, and transfer management. However, many transfer cases in practice are still not enforced, such as the relationship between the transfer and the alteration of the right of sea area use, the transfer of ownership, etc. Therefore, it can be pointed out that the system of transfer of sea use rights in our country is still not perfect.

Some maritime administrations of local coastal governments have promulgated provisions on the transfer of the right to use local sea areas (Table 2) according to the "Sea Area Law" and the "Regulations on the Administration of Sea Area Use Rights". For example, in 2003, Beihai Government of Guangxi promulgated the Interim Provisions on the Management of the Transfer of the Use Right of the Beihai Sea and made special regulations on the transfer of the right to use the Sea Area. In addition, both Putian, Fujian Province in 2009 and Weifang, Shandong Province in 2013 introduced regulation on the transfer of the right of use of the sea.

In terms of transfer fees, "the Interim Provisions on the Use of the State Sea" ([Cai Zongzi No. 73 [93]) promulgated by the Ministry of Finance in 1993 stipulated that the funds for use in the sea area shall include the sea area transfer fees, the sea area transfer fees and the sea area rentals. It shall be turned over to the administrative department of the sea or the financial department according to the proportion of not less than $40 \%$ of the added value of the transfer. And in the local supporting documents, it is required that the transfer of the right to use the sea area be subject to the transfer payment. Thus, in 2008 the Ministry of Finance abolished the document.

On January 6, 2012, the Ministry of Finance and the State Administration of Taxation jointly promulgated "the Circular on the Business Taxation on the Transfer of Use Rights of Natural Resources" (Cai Shui [2012] No. 6), which stipulated that the tax items of "transfer of intangible assets" added with "Transfer of natural resources" and ensure that the natural resource use rights should include the right to use the sea.
TABLE II. TRANSFER REQUIREMENTS FOR THE MANAGEMENT OF THE TRANSFER OF RIGHTS TO USE OF SOME LOCAL SEAS (PROVINCIAL LEVEL)

\begin{tabular}{|c|c|c|}
\hline $\begin{array}{c}\text { Province } \\
\text { (autonomous } \\
\text { regions and } \\
\text { municipalities) } \\
\end{array}$ & Management policy & Regulations \\
\hline Shandong & $\begin{array}{c}\text { The Interim Measures } \\
\text { of Sea Use } \\
\text { Expenditure Collection } \\
\text { and Management in } \\
\text { Shandong Province }\end{array}$ & $\begin{array}{l}\text { Extra tariffs of } 40 \% \text { of the } \\
\text { added value from the } \\
\text { transfer of the sea use. }\end{array}$ \\
\hline Shanghai & $\begin{array}{c}\text { The Management } \\
\text { Approach of Sea Use } \\
\text { Expenditure Collection } \\
\text { in Shanghai City }\end{array}$ & $\begin{array}{l}\text { Extra tariffs of } 40 \% \text { of the } \\
\text { added value from the } \\
\text { transfer of the sea use. }\end{array}$ \\
\hline Jiangsu & $\begin{array}{c}\text { The Management } \\
\text { Approach of Sea Use } \\
\text { Expenditure Collection } \\
\text { in Jiangsu Province }\end{array}$ & $\begin{array}{l}\text { Extra tariffs of } 30 \% \text { of the } \\
\text { added value from the } \\
\text { transfer of the sea use. }\end{array}$ \\
\hline Zhejiang & $\begin{array}{l}\text { The Management } \\
\text { Approach of Sea Use } \\
\text { Expenditure Collection } \\
\text { in Zhejiang Province }\end{array}$ & $\begin{array}{l}\text { Extra tariffs of } 40 \% \text { of the } \\
\text { added value from the } \\
\text { transfer of the sea use. }\end{array}$ \\
\hline Fujian & $\begin{array}{c}\text { The Supporting } \\
\text { Management Approach } \\
\text { of Sea Use } \\
\text { Expenditure Collection } \\
\text { in Fujian Province }\end{array}$ & $\begin{array}{l}\text { Extra tariffs of } 40 \% \text { of the } \\
\text { added value from the } \\
\text { transfer of the sea use. }\end{array}$ \\
\hline Guangdong & $\begin{array}{c}\text { The Interim Measures } \\
\text { of Sea Use } \\
\text { Expenditure Collection } \\
\text { and Management in } \\
\text { Guangdong Province }\end{array}$ & $\begin{array}{l}\text { Extra tariffs of } 40 \% \text { of the } \\
\text { added value from the } \\
\text { transfer of the sea use. }\end{array}$ \\
\hline Guangxi & $\begin{array}{l}\text { The Management } \\
\text { Approach of } \\
\text { Maritime Rights in } \\
\text { Transfer, Lease and } \\
\text { Mortgage in Guangxi } \\
\text { Zhuang Autonomous } \\
\text { Region (Trial) } \\
\end{array}$ & $\begin{array}{l}\text { The conditions for the } \\
\text { transfer of the right to use } \\
\text { the sea shall transfer the } \\
\text { materials submitted by both } \\
\text { parties to the original sea } \\
\text { department for approval. }\end{array}$ \\
\hline Hainan & $\begin{array}{c}\text { The Management } \\
\text { Approach of Sea Use } \\
\text { Expenditure Collection } \\
\text { in Hainan Province }\end{array}$ & $\begin{array}{l}\text { Extra tariffs of more than } \\
40 \% \text { of the added value } \\
\text { from the transfer of the sea } \\
\text { use. }\end{array}$ \\
\hline
\end{tabular}

\section{Sea area mortgage system}

The right of use of sea area mortgage refers to that the creditors can dispose of maritime rights and have the priority to the discounting price if the obligation to guarantee creditor's rights were not ensured in the condition that the sea user didn't change the use right. In this legal relationship, the party that provides the right to use the sea area as collateral is the mortgagor, and the entity that accepts the sea area use right guarantee is the mortgagee.

The "Law of the People's Republic of China on the Administration of the Use of the Sea Area" established the system of management of the right to use the sea area. More and more sea users are required to mortgage the right to use the sea area. Since 2004, the "Guidance on the Administration of Sea Area Utilization" has appeared in the information on the mortgage of sea area use rights. And since 2005, it included statistics on the mortgage of sea area use. Furthermore, in 2005, 659 mortgage-related sea use rights in China were consulted, covering the area of the sea area about $29,600 \mathrm{hm} 2$. Over the years, the mortgage-free right to use sea area has been on the rise. In 2015 , a total of $122,000 \mathrm{hm} 2$ of 
waters across the country were mortgaged for use of maritime space and the loan amount reached 34.478 billion yuan.

Sea area rights mortgage transactions are on the increase. The marine administrative departments and financial regulatory authorities across the country have realized the needs of market development and introduced relevant policies and measures. Most of which are jointly issued by the marine management and financial management departments, and some marine administrative departments also promulgated relevant policies specifically for the issue of mortgage of maritime usage rights, such as mortgage registration. At present, there are six coastal provinces, municipalities or autonomous regions have promulgated relevant policies for the right of use of sea areas, including Tianjin, Shandong, Jiangsu, Zhejiang, Fujian and Guangxi (Table 3). In which Fujian Province issued the Registration of Mortgage Registration as early as 2006 Method. There are two types of local management policies that have been promulgated: one is the registration and management policy for the mortgage of sea-use rights; and the other is the mortgage loan policy for the right to use sea areas. In addition, some coastal cities and counties also have promulgated or are introducing the mortgage-management policies on the right of using sea areas, such as Lianyungang and Yancheng in Jiangsu. Compared with the marine administrations, there are very few management policies promulgated by the financial administrations for the right to use sea areas [6].

TABLE III. THE MORTGAGE MANAGEMENT POLICY OF RIGHT TO USE SEA IN PARTIAL COASTAL AREAS (PROVINCIAL LEVEL)

\begin{tabular}{|c|c|c|c|}
\hline $\begin{array}{l}\text { Province (autonomous } \\
\text { regions and } \\
\text { municipalities) }\end{array}$ & Management policy & Departments & Time \\
\hline \multirow{2}{*}{ Tianjin } & $\begin{array}{c}\text { Opinions on the Implementation of Mortgage and } \\
\text { Loan of Tianjin Sea Use Right (2009.11.18) }\end{array}$ & Tianjin Banking Bureau \& Tianjin Maritime Bureau & \multirow{2}{*}{2009} \\
\hline & $\begin{array}{c}\text { Mortgage Registration of Tianjin Sea Area Right } \\
(2009.11 .18)\end{array}$ & Tianjin Maritime Bureau & \\
\hline Shandong & $\begin{array}{l}\text { Opinions on the Implementation of the Mortgage of } \\
\text { Sea Use Right in the Island of Shandong Province }\end{array}$ & $\begin{array}{l}\text { Shandong Finance Office, Shandong Provincial Department of } \\
\text { Ocean and Fishery, Jinan Branch of the People's Bank of China, } \\
\text { and Shandong Province Banking Bureau }\end{array}$ & 2011 \\
\hline \multirow[t]{2}{*}{ Jiangsu } & $\begin{array}{l}\text { Notice on Advancing the Opinions on the Use of } \\
\text { Mortgage-Loan for the Right to Use Sea Areas } \\
\text { (2009.08.31) }\end{array}$ & $\begin{array}{c}\text { Jiangsu Provincial Oceanic and Fishery Bureau, Jiangsu } \\
\text { Provincial Government Finance Office, People's Bank of China } \\
\text { Nanjing Branch, and Jiangsu Banking Bureau } \\
\end{array}$ & \multirow[t]{2}{*}{2009} \\
\hline & $\begin{array}{c}\text { Provisional Measures on Mortgage Registration of } \\
\text { Jiangsu Province Sea Area Use Right } \\
\end{array}$ & Jiangsu Provincial Oceanic and Fishery Bureau & \\
\hline \multirow{2}{*}{ Zhejiang } & $\begin{array}{c}\text { Opinions on Carrying out the Mortgage Loan of } \\
\text { Sea Use Right }\end{array}$ & Zhejiang Government & \multirow{2}{*}{2010} \\
\hline & $\begin{array}{c}\text { Measures for the Administration of Registration of } \\
\text { Mortgage Rights in Zhejiang Province }\end{array}$ & Zhejiang Marine and Fishery Bureau & \\
\hline Fujian & $\begin{array}{c}\text { Measures for the Administration of Registration of } \\
\text { Mortgage Rights Non-residents Rights in Fujian } \\
\text { Province (2013.07.14) }\end{array}$ & Fujian Provincial Department of Ocean and Fisheries & 2013 \\
\hline Guangxi & $\begin{array}{l}\text { The Management Approach of Maritime Rights } \\
\text { Transfer Lease Mortgage in Guangxi Zhuang } \\
\text { Autonomous Region }\end{array}$ & $\cdots$ & 2011 \\
\hline
\end{tabular}

\section{Sea Price Assessment System}

On January 1, 2002, the "Law of the People's Republic of China on the Administration of the Use of the Sea Area" was formally implemented. From the legal aspect, the establishment of the maritime ownership management system and the system of compensation for use in our country and so many other systems ended the history of the disorderly, unscrupulous and unpaid use of the sea area. Since the market of the sea area was not yet established and the market price of the sea area had not yet been formed, the State Oceanic Administration organized technical units to make levies on the use of fee collected from the sea area and calculate the different types of levied expenditure on the basis of the national sea classification. Subsequently, State Oceanic Administration jointly promulgated the Circular on Strengthening "the Administration of Levy of Use of Sea Area Expenditure". On March 1, 2007, the unified use of expenditure in the sea area was calculated according to the type of sea, the sea area and the corresponding levying standards. The establishment of the sea area expenditure standard marks the beginning of China's sea area price evaluation system.

After the establishment of the system of paid use in the sea, the market-oriented allocation of resources in the sea sprouts. The bidding, auction and listing of the right to sell the use of the sea involves the determination of the reserve price. The transfer of the right to use the sea involves the determination of the added value of the sea area, the compensation of the sea area use right, and the early recovery of the sea area right. A series of maritime market activities have a strong demand for the sea area price assessment. In order to guide the sea price assessment intermediary industry to develop healthily, the State Oceanic Administration actively promotes the establishment of a sea area price assessment technical system and the construction of a price assessment team in the sea area In 2012, upon recommendation by sea administrative departments of coastal provinces and autonomous regions, Sea area price assessment business agencies to determine the list of recommended marine assessment agencies. In the end of 2012, the State Oceanic Administration started the first phase of the national assessment of the sea business training courses, 
training and issuing job training certificates. In addition, in the end of 2013, the State Oceanic Administration issued a "sea area Evaluation of Technical Guidelines "for the sea price assessment, which provides a certain degree of technical support [7].

\section{PROBLEMS FACING THE SYSTEM OF MARKET ALLOCATION OF RESOURCES IN THE SEA AREA}

At present, the coastal provinces and municipalities have actively explored the marketization and allocation of sea resources and the results are worthy of recognition. However, due to the special nature of sea resources, the overall marketization is still in its infancy. There are still many imperfections in the marketization of sea resources to be improved in the future.

\section{A. Rights protection issues}

The protection of rights and interests mainly involves four aspects: First, the protection of maritime areas of national rights and interests. Marketization is price-oriented. However, the sea area is a national resource. How to accurately evaluate the sea area including the resource elements, environmental capacity and ecological functions, and set the bottom line is the first issue to be solved in the marketization of sea area allocation. The second is to protect the rights and interests of sea people. Due to the actual conditions, the legal persons or persons authorized to obtain sea-based rights through marketization, whether they can obtain sea-based right on schedule and early recovery due to the right of use such as public interests or national security needs, and how to compensate for such losses, are still lacking effective protection. Third, the "loss of sea" fishermen living security issues. The collection and storage of the sea area may lead some specialized fishermen to "lose the sea" and lose their livelihood guarantee. How these people will be resettled will affect the overall social stability. Fourth, the protection of the right to information. The collection, compilation and release of information on the transfer, leasing and mortgage of the sea area are not yet established at present. The low degree of openness of the market allocation of maritime information provides neither a timely and comprehensive basis for government decision-making and related supervision, but also affects the bidders' Judgment and participation in competition.

\section{B. Sea area right price assessment unscientific, sea area waste of resources}

The price is the monetary manifestation of the commodity value. The marine resources itself has the social value, the economic value, the ecological value. whether the value of sea resources can be realized depends on Whether the price is reasonable or not. The current laws and regulations on the application for approval, bidding, the auction should follow the conditions, procedures did not make specific provisions. In actual practice, the amount of money paid by the sea area is often used as a criterion for judgment. "Whoever uses more gold in the sea areas will obtain the right to use the sea area." This has led to the phenomenon of "circle of sea" frequently occurring in well-funded units and individuals, making it impossible to plan, exploit or effectively make use of the acquired sea areas after the seamen has acquired the sea area, and may even have "idle sea" and "waste sea ", resulting in a huge waste of resources in the sea. For those who really need sea areas, fishermen and farmers in particular may lose the opportunity to use the sea, causing "loss of sea" and "unemployment", which will be detrimental to social stability.

\section{The scope of application of the transfer management}

In the current management, all provinces and cities "transfer method" requires that the sea of applications for industrial, commercial, tourism, entertainment and other operating projects and the sea for which there are more than two identical sea areas in the same sea should be used auction way to sell. However, some provinces made more specific use of the "Measures for the Assignment" and demanded that other than the six sea projects including land for construction purposes, provincial key projects, national project aquaculture projects and fishing port projects should be marketed, and stressed that for real estate development should be sold by auction. More special is the use of aquaculture, its income is lower than other sea types. If we use the method of bidding auction to sell the use rights of farming sea, it will greatly increase the cost of units intend to it. Some provinces and municipalities have stipulated that the units intend to use seabased may not apply for sea-use rights certificates.

\section{Sea area use and land use issues}

In the reclamation of the sea, the coastal provinces and cities have some discrepancies in the transfer of the right to use the sea and the land. For example, they are separated in Hainan and merged in Fujian and the use of sea area and landuse fees after the transfer are not the same. Fujian is a onetime charge through the merger and transfer, and then with the land administration department in accordance with a certain percentage of distribution, while the use of the sea by the marine administrative department in accordance with the provincial, municipal and county ratio of 2: 1: 7 into, respectively, state-level treasury. Hainan Province will charge a fee for use of the sea area after bidding and auctioning of the right to use the sea area. After the completion of the reclamation project, when the land use right certificate is changed, the land transfer fee will be paid according to the market assessment results. The paid sea area fee and reclamation cost should be offset. How to balance the use of sea area and land use also needs further study.

\section{COUNTERMEASURES FOR PERFECTING MARKETIZATION OF SEA AREA TRANSFER MANAGEMENT SYSTEM}

\section{A. Speed up the marketization management of marine resources}

As an important breakthrough in regulating the use and management of marine areas, the marketization of marine resources plays an important role in optimizing the allocation of sea resources and improving the efficiency of comprehensive utilization. Therefore, it is imperative to speed up the marketization management of marine public resources. First, the comprehensive and coordinated use of a variety of management tools to promote the marketization of marine 
resources management process. The basic means of marketization management of marine resources include administrative measures, legal management measures and economic management measures. In order to promote the marketization of marine areas, these management measures need to be integrated and coordinated. Among them, the means of administrative management has been the main means of management in the management of maritime areas. It has the characteristics of convenient operation and flexible mobility. However, the market-based management of maritime areas involves complicated distribution of benefits and cannot be solved by administrative means alone. We must also play a legal norm, the role of economic management tools. Second, the newly approved aquaculture seas around the country should all be auctioned and linked to promote the marketization of marine resources. At the same time, on the basis of thorough investigation, gradually expand the scope of market allocation of sea resources in the offshore coast. Third, the financial sector and the marine fishery management departments at all levels should make active and timely policies to promote the use of mortgage loans in sea areas. In response to the difficulties of sea users in the financing process, the marine fishery management departments at all levels should actively discuss with the financial sector about the synergies of mortgage loans for sea area use rights, make efforts to broaden the financing channels for those who use sea areas, and gradually implement the ownership mortgage loan system and give full play to the role of the right to use sea area mortgage in activating assets, ensuring credit and promoting production, and forming more market-oriented bidders for the right to use sea areas, so as to create a precondition for activating the marine market.

\section{B. Establish a relatively centralized and unified marine integrated management system}

The opportunities and challenges our country's marine undertakings face are demanding the enhancement of integrated ocean management. Based on the interdependence and role of ocean affairs, marine integrated management integrates the priorities concerning national interests so that the development in the maritime field can be better integrated with the major national policies of the country. Through comprehensive, unified management to coordinate and solve problems in the sustainable development of the oceans and seas. The establishment of a comprehensive marine management system should include the establishment of a relatively centralized marine integrated management agency, the establishment of a high-level coordinated management system, coordination and resolution of major maritime issues, breaking the division of the marine industry, changing the management of marine affairs and achieving unity management, unified market. In particular, marine administrative departments with higher authority and responsibility should be established. At the central level, the Marine Integrated Management Committee directly under the State Council shall be established to exercise unified responsibilities in maritime management and to coordinate marine management. At the local level, awareness of marine management should be enhanced and corresponding integrated ocean management agencies established to coordinate and coordinate the efforts of the central and local governments marine management, safeguard the national maritime rights and interests, develop and utilize marine resources, protect the marine ecological environment, and develop marine industries in the coastal areas.

\section{Cultivate the operating environment for the market- oriented allocation of sea resources}

In the current situation, breakthroughs should be made in the following aspects: First, to strengthen the construction of relevant laws and regulations so that market-based allocation of resources in the ocean can be regulated by law. On the one hand, local laws and local government regulations that are inconsistent with national laws should be promptly cleared and amended; the authority and seriousness of state laws should be upheld; and the order of maritime administration should be maintained. On the other hand, the national legislature should take relevant steps as soon as possible on the basis of earnest research to formulate special regulations on the market-oriented allocation of resources in the sea area. Special regulations on the allocation of resources in the sea area, the compensation mechanism for the use of sea areas, the transfer and transfer of tenure ownership, the procedures and methods for marine administrative management, registration and other issues to make a special legal provision so that the marketization of resources in the sea area can truly be incorporated into the track of laws and the rule of law and promote the scientific and standardized management of maritime areas. Second, to establish a fair market competition environment configuration. The market environment of equal competition is an important platform for the market-oriented management of marine resources. Therefore, the marketoriented allocation of resources in the maritime areas should carry out large-scale public information through the public media such as the Internet and television and widely disseminate various types of information and timely public configuration procedures, processes and result, market participants can maximize their access to information and effectively enhance the transparency of their deployment. At the same time, we should give full play to the role of public resource trading centers, tendering and bidding regulatory centers, and economic contract review service centers at all levels to strengthen the supervision of the whole process of the allocation of resources in the sea and create favorable conditions for fair and orderly competition. Third, form an open, fair and orderly allocation system. The coastal governments at all levels should start from the aspects of planning, assessment, auditing, trading and supervision and actively establish such supporting systems as marine project audit, assets assessment, credit mortgage and circulation supervision so as to ensure the sustainable and healthy development of the market-oriented allocation of sea resources. Such as improving the right to use the sea mortgage registration system, the establishment of expert review and project review system.

\section{Establish and improve the value assessment system of marine resources}

Scientifically and reasonably collecting and remitting the use of sea area gold and the transfer of the right to use the sea 
area, and determining the ecological compensation and damage compensation for the right to use the sea area all need a normative assessment of the value of the sea area resources. First of all, do a good job in the sea area benchmark price assessment. The reference price of the sea area should correctly reflect the average price level of the transfer of the sea area use rights in a certain period of time and macrocontrol the price of the transfer of the right of use of the sea area so as to ensure that the gold standard of sea area use in the whole country is generally fair and reasonable so as to coordinate economic development. Secondly, starting from the needs of the market management of the sea area, do a good job of sea price assessment. In order to assess the price of the sea, it is necessary to base on the benchmark price and the gold standard set by each coastal area, taking into account the actual quality and income levels of the coastal areas under jurisdiction and the market conditions in the sea. Thirdly, we should establish a mechanism for the recovery of sea areas and ensure that the state monopolizes the maritime market. Use the necessary sea area recovery mechanism to meet the needs of public marine major marine construction projects and to take advantage of the state's right to dispose of sea areas and stop the loss of sea value added to private sources and control the speculative activities in the sea areas through the recovery of expired and underperforming sea areas. When recycling poorly managed sea areas, they should be compensated reasonably.

\section{E. Strengthen supervision and administration and promote the transparency of market allocation in the sea area}

First, give full attention to the role of supervision. We must include the marketization of the deployment of the sea area in the work on combating corruption and building a clean government. We should establish a supervision system consisting of higher-level maritime authorities, discipline inspection departments at the same level, people's deputies, CPPCC members, public opinion and mass representatives, and clear their respective responsibilities in the audit, confirmation, supervision and filing review. Second, it is necessary to speed up the improvement of supervision measures and ensure that people have full rights of information, participation and supervision, and provide detailed provisions on the law and discipline provisions for violations of discipline and law in the market-oriented allocation of the sea areas, prevent subcontracting and subcontracting, avoid bidding, illegal listing, illegal transfer and other acts. The third is to increase accountability efforts. It is necessary to strictly supervise the key intermediary agencies such as the bidding and bidding of sea areas and other key intermediary agencies for assessment, planning and auditing of the sea areas. The unlawful transfer of the right to use the sea area into the market is not paid. The publicity of this bid is not disclosed. In particular, party members and leading cadres who use their powers to intervene in the trading market should conduct serious investigation and punishment, give heavy penalties and give full play to the deterrent effect of supervisory power, ensure the serious and orderly regulation of the market allocation of sea areas and truly achieve the "sunshine " market.

\section{CONCLUSION}

The market allocation of marine resources is a very short process. Compared with the land transfer management system, its system has some problems and deficiencies. These issues may be related to the continuation of the "examination and approval system" thinking in the traditional maritime areas or to the imperfection of coordination among other relevant management departments and the maritime administration departments in the transfer of sea areas. However, it is an inevitable choice to introduce market measures, standardize and establish a two-level market for the use of maritime space and ensure fair and equitable distribution of resources in the sea areas. In accordance with the principle of market economy and the law of value, the establishment of a market-oriented allocation mechanism for the use of sea areas in accordance with the law is of great importance to further improving the market access for sea areas, introducing market competition to select sea operators and developers, preventing unfair competition and corruption, and the maximization of the economic benefits of resources. It is of great significance to implement the economic autonomy of sea users, optimize the allocation of marine resources, improve the utilization efficiency of marine resources, protect the marine resources and environment, promote the sustainable utilization of marine resources and comprehensively improve the integrated marine management.

\section{REFERENCES}

[1] Chen Shuquan. Research on the Problems and Countermeasures of Market Management of Marine Resources[J]. Shandong Social Sciences, 2012, (5): 36-41. (In Chinese)

[2] Cao Yingzhi. Study on the Marine Resource Allocation Method[D]. Qingdao: Ocean University of China, 2014. (In Chinese)

[3] Jiang Bendong. Rediscussion on the Tackle of Transformation of Resource Allocation Mechanism[J]. Dong Yue Tribune, 2003, (1):34(In Chinese)

[4] Zheng Guibin, Sun Jitin. Preliminary Study on Circulation of Usufruct of China's Sea Area [J]. Dong Yue Tribune, 1998, (5):55. (In Chinese)

[5] Fei Hongda, Li Mingyang. Reflections on the Legal System of the Transfer of the Right to Use Sea Areas in China[J]. Cognition and Practice, 2016, (3):30-33. (In Chinese)

[6] Liu Shufen, Hou Zhiyang, Xu Wei, Zhao Meng. The Present Situation and Management Policy Suggestions of the Right of Use of Sea Area in China[J]. Ocean Development and Management, 2016, (2):81-83. (In Chinese)

[7] Cai Yueyin, Wang Peng, Gao Bei, Gong Wei. Status quo, problems and countermeasures of price assessment in China seas $[\mathrm{J}]$. Ocean Development and Management, 2016, (9):23-26. (In Chinese) 